\title{
FORUM
}

\section{VN-verdrag handicap}

\section{Een brede visie op toegankelijkheid}

\author{
Jiska Ogier
}

De datum van de inwerkingtreding van het VN-verdrag inzake de Rechten van Personen met een Handicap (VN-verdrag Handicap), 14 juli 2016, had een bijzondere lading voor de ervaringsdeskundige jongvolwassenen van Wij Staan Op!, onder wie ondergetekende. Het Handvest voor Vrijheid, Gelijkheid en Menselijkheid had namelijk als oorspronkelijke ondertitel Een modern pleidooi met een knipoog naar de Franse revolutie. ${ }^{1}$ Naar de ratificatie van het verdrag op Quatorze Juillet werd bijna tien jaar reikhalzend uitgekeken door grote groepen mensen met een handicap of chronische ziekte. Het jaar 2021 markeert vijf jaar VN-verdrag handicap. Hoewel de grondslagen ervan de afgelopen jaren steeds meer bekendheid kregen binnen de Nederlandse gehandicaptengemeenschap, bleven de grote veranderingen waar velen op hoopten uit.

Belangrijk onderwerp van gesprek was in ieder geval wel de met het verdrag voorgestane transitie van het medisch model naar het sociale model. In Nederland is op dit moment nog vaak het medisch model overheersend. Hierbij wordt gedacht vanuit beperkingen en het ondersteunen van mensen vanuit een zekere behoefte om hen aan de norm te laten voldoen. Het VN-verdrag Handicap daarentegen gaat veel meer uit van het sociale model. Hierbij staat menselijke gelijkwaardigheid centraal, waarbij in sommige gevallen een ondersteuningsbehoefte hoort. ${ }^{2}$ Hoewel het sociale model voor velen de voorkeur heeft, doet het mijns inziens de enorme diversiteit aan ondersteuningsbehoeften van mensen met een handicap tekort. Het culturele model biedt daarvoor een middenweg: hierin hebben het medische en sociale model beide een plaats. Afhankelijk van de situatie kan er gekozen worden voor het best passende model. Gaat het om een gezondheidsvraagstuk dan kan het medische model zeer toepasselijk zijn, zonder daarbij afbreuk te doen aan de sociale gelijkwaardigheid. ${ }^{3}$

\section{Levenslang en levensbreed}

De toepassing van bovenstaande modellen raakt direct aan een belangrijk besef: toegankelijkheid, maar zeker inclusie, is veel meer dan alleen het drempeltje voor 
de deur. ${ }^{4}$ Juist dit besef lijkt nog lang niet te zijn doorgedrongen bij wetgever en beleidsmakers. Het onderscheid tussen fysieke toegankelijkheid en sociale toegankelijkheid - de ervaring dat men welkom is met de beperkingen behorend bij de persoon - is lang niet altijd terug te zien in de beleidsmatige uitvoering van het VN-verdrag Handicap. Daarbij is niet alleen van belang dat er een onderscheid wordt gemaakt tussen de verschillende soorten toegankelijkheid, maar ook de doelgroep moet scherp in het oog worden gehouden. Geconstateerd kan worden dat er nauwelijks onderscheid wordt gemaakt tussen ouderen die door leeftijd beperkingen gaan ervaren, en mensen met een levenslange en levensbrede handicap. Een goed voorbeeld van dit gebrek aan onderscheid is dat informateur Mariëtte Hamer tijdens de formatieperiode overleg had met ouderenorganisaties, maar niet sprak met organisaties die een bredere visie hebben op gehandicaptenbeleid. ${ }^{5} \mathrm{Ou}$ derenbeleid wordt vaak onbewust gelijkgesteld aan gehandicaptenbeleid, waardoor niet alle levensterreinen aan bod komen.

Wanneer de focus ligt op een specifieke subgroep van een doelgroep kun je nooit een integrale aanpak creëren voor de gehele groep mensen met een beperking. De uitvoering van het VN-verdrag Handicap werd gedaan door middel van het programma Onbeperkt Meedoen. Dit programma werd ondergebracht bij het ministerie van Volksgezondheid, Welzijn en Sport (VWS). ${ }^{6}$ Hiermee werd afbreuk gedaan aan de integrale visie van het VN-verdrag Handicap dat juist ook gaat over de sociaaleconomische positie van mensen met een handicap (SZW), evenals vraagstukken rondom wonen (BZK), onderwijsproblematiek (OCW) en toegankelijk (openbaar) vervoer (I\&W).

Juist die integrale aanpak is onontbeerlijk bij de weg naar inclusie. Een simpel voorbeeld laat goed zien waarom: wie afhankelijk is van persoonlijke verzorging bij het opstaan en/of aankleden heeft hier niet alleen mee te maken vanuit een zorgperspectief, maar de betrouwbaarheid van deze zorg bepaalt ook de rest van de dag. Hetzelfde geldt voor toegankelijk (openbaar) vervoer. Zelf in de auto kunnen stappen of zelfstandig gebruik kunnen maken van het openbaar vervoer geeft veel meer vrijheid dan doelgroepenvervoer waarbij vaak sprake is van marges in de tijden of het boeken van assistentie waarbij men eerder aanwezig moet zijn en overstappen meer tijd kost. Die vrijheid komt in het gedrang als de persoonlijke verzorging al niet goed te plannen is. Beide factoren, zorg en vervoer, hebben vervolgens weer hun uitwerking op de mogelijkheden die iemand heeft om doelmatig te participeren in onderwijs of (betaald) werk. Hoe bereidwillig zou u als werkgever zijn wanneer een werknemer structureel onregelmatig werkt, dit niet kan plannen en mogelijk ook nog een andere werkwijze heeft dan u gewend bent? Deze vraagstukken geven direct goed aan waarom het onwenselijk is mensen met een levensbrede en levenslange handicap en ouderen als één groep te beschouwen; hun leefwerelden zijn wezenlijk verschillend.

5 www.kabinetsformatie2021.nl/actueel/nieuws/2021/05/27/informateur-ontvangt-vertegenwoordigersvan-de-themas-ouderen-duurzaamheid-en-digitalisering.

6 Kamerstukken II 2017/18, 24170, nr. 177 en bijlage Onbeperkt Meedoen. 


\section{Energielekken}

Een andere belangrijke drempel voor veel mensen met een handicap of chronische ziekte om te participeren is de energie die het hebben van een handicap of chronische ziekte kost. Hierin zijn twee energielekken te onderscheiden: in sommige gevallen veroorzaakt de handicap zelf een beperking in de energie, daarnaast is er ook sprake van veel verborgen arbeid. ${ }^{7}$

De lepeltheorie is een veelgebruikte uitleg voor het hebben van een energiebeperking. Kortgezegd betekent het dat mensen met een handicap een beperkt aantal lepels hebben per dag. Elke activiteit - opstaan, eten, aankleden, medicatie innemen enzovoort - kost een lepel. Zijn de lepels op, ook al is de dag nog niet voorbij, dan kan men niet meer functioneren. ${ }^{8}$ Een gedetailleerdere illustratie is de vergelijking met een oudere smartphone waarvan de batterij sneller leegloopt dan die van een nieuwe. Daarnaast kost de ene app meer batterijpercentage dan de andere app. Bovendien geeft de smartphonevergelijking ruimte voor de 'achtergrondapps' die veel mensen met een handicap op de achtergrond hebben draaien; zorgen over de toegankelijkheid van een locatie, het uitgebreid moeten plannen van een reis in verband met begeleiding en extra oplettendheid omdat de wereld niet op hen is ingericht. Naarmate de batterij leger raakt, kosten taken extra tijd en moeite, tot het functioneren uiteindelijk helemaal stagneert. Deze achtergrondapps kunnen ook wel verborgen arbeid genoemd worden, het tweede energielek.

Verborgen arbeid kan zowel fysiek als emotioneel zijn. Naast de hierboven genoemde 'achtergrondapps' kan er ook nog gedacht worden aan de beperking vaak moeten uitleggen, druk voelen om aan verwachtingen te voldoen en veel regelwerk rondom het verkrijgen van zorg. De energie die verborgen arbeid kost, is voor een groot deel afhankelijk van de maatschappelijke omgang met mensen met een handicap. Het bij de ratificatie van het VN-verdrag Handicap aangenomen amendement-Van Dijk pleitte destijds al voor toegankelijkheid als norm en verplichte informatie over die toegankelijkheid via websites. ${ }^{9}$ Daarmee wordt het makkelijker voor mensen om voor zichzelf te bepalen of een locatie toegankelijk is voor hen. Toegankelijkheid is niet voor iedereen hetzelfde; wie een elektrische rolstoel gebruikt, heeft minder last van een steile helling maar heeft misschien een grotere draaicirkel, daar waar het voor gebruikers van een handbewogen rolstoel precies andersom is. Ook bij verschillende beperkingen speelt dit een rol; wie een taststok gebruikt, heeft baat bij geleidelijnen terwijl een gebruiker van rolstoel of rollator daar juist last van kan ondervinden.

\section{Bestaanszekerheid}

Naast fysieke bestaanszekerheid - de kwaliteit van hulpmiddelen en zorg bepaalt mede iemands kwaliteit van leven - is de financiële positie van mensen met een arbeidsbeperking al jaren punt van discussie. De invoering van de Participatiewet 
in 2015 alsmede de nadere uitwerking daarvan hebben al verschillende keren voor grote maatschappelijke ophef gezorgd. ${ }^{10}$ In het breed advies van het College voor de Rechten van de Mens uit februari 2020 werd dan ook aangehaald dat de verschillende regels en rekenmodellen voor veel onrust zorgen en tot gevolg hebben dat velen niet zelfstandig rond kunnen komen. Mensen die wel rondkomen, voelen zich door hun vaak lagere inkomen bovendien vaak beperkt in veel sociale activiteiten, zoals het drinken van een kopje koffie in de horeca. ${ }^{11}$

De aantekening van het College illustreert goed het levensbrede aspect van het hebben van een handicap. Wie elke euro omdraait, neemt minder deel aan het maatschappelijke leven, is als consument minder actief in de economie en zal minder snel een financieel risico nemen. Door de verschillende en vaak complexe rekenmethodes die worden gebruikt voor het verrekenen van uitkeringen wordt (meer) gaan werken door deze groep - die daartoe door de overheid juist gestimuleerd wordt - vaak als risico ervaren. Belangrijke noot hierbij is dat mensen met een arbeidsbeperking een relatief kleine rol hebben gespeeld bij de totstandkoming van de Participatiewet, die juist bedoeld is om deze groep naar werk te stimuleren. Hier ligt een duidelijke taak voor de wetgever om het VN-verdrag Handicap beter toe te passen door inzet van ervaringsdeskundigheid vanaf het begin. ${ }^{12}$

Een extra heikel punt hierbij zijn de extra kosten die veel mensen met een handicap hebben. Denk daarbij aan het eigen risico bij een zorgverzekering, eigen bijdragen voor hulpmiddelen, zorg en medicatie, maar ook onzichtbare extra kosten zoals afhankelijkheid van bepaalde producten die zelf worden aangeschaft of het rijden van een minder zuinige auto omdat deze geschikt is voor rolstoelvervoer. Deze extra kosten worden sinds de afschaffing van de Wet tegemoetkoming chronisch zieken en gehandicapten nergens meer gecompenseerd, en ook verschillende aftrekposten zijn versoberd of afgeschaft. ${ }^{13}$

\section{Ervaringsdeskundigheid}

De inzet van ervaringsdeskundigheid blijkt een algemeen punt waarop de Nederlandse wetgever nog veel winst te behalen heeft, zo oordeelde het College voor de Rechten van de Mens in de jaarlijkse rapportage van 2020. ${ }^{14}$ Daarbij kan ook opgemerkt worden dat het beloningsbeleid voor ervaringsdeskundigen tekortschiet. Hiermee geeft de wetgever een duidelijk signaal af dat niet past bij de ambities van het VN-verdrag Handicap: meepraten lijkt nog altijd gezien te worden als gunst in plaats van als waardevol ervaringsdeskundig advies. 


\section{Implementatie}

De overheid heeft nog veel te doen wat betreft de implementatie van het VN-verdrag Handicap. De jaren na ratificatie hebben nog niet gezorgd voor de grote stappen die nodig zijn om van Nederland ook voor mensen met een handicap een inclusieve samenleving te maken. Integendeel, de financiële positie van sommige groepen lijkt juist achteruitgegaan te zijn. ${ }^{15}$ Daarmee treedt de wetgever het standstill-beginsel - dat juist stelt dat de positie van mensen nooit achteruit mag gaan na tekenen van een verdrag - met voeten. ${ }^{16}$ Hoewel het verdrag steeds meer bekendheid geniet en langzaamaan meer in de jurisprudentie teruggevonden kan worden, blijkt het in de praktijk nog moeilijk de benodigde ervaringsdeskundigheid aan tafel te krijgen bij de wetgever. ${ }^{17}$ De rechtstreekse werking van het VN-verdrag lijkt beperkt, ondanks de ruime interpretatie van de Hoge Raad. ${ }^{18}$ Wel kan verwacht worden dat de Nederlandse rechter het recht conform het internationale recht en dus het verdrag uitlegt. ${ }^{19}$ Hiermee wordt echter bij lange na niet voldaan aan de visie van het verdrag dat een algemene verbetering van de positie van mensen met een handicap nastreeft, met daarbij de actieve betrokkenheid van ervaringsdeskundigen. ${ }^{20}$

\section{Conclusie}

Vijf jaar na de ratificatie van het VN-verdrag Handicap blijven grote veranderingen uit. Vooral de inzet van ervaringsdeskundigheid, bestaanszekerheid en de energielekken die mensen met een handicap ervaren, verdienen meer aandacht dan ze nu lijken te krijgen. In de praktijk blijkt de positie van mensen met een handicap de laatste jaren onvoldoende vooruitgegaan te zijn. De wens van een toegankelijke samenleving lijkt daarmee voorlopig nog niet in vervulling te gaan. Het is van groot belang dat ervaringsdeskundigen op grotere schaal gehoord worden om hun positie in beleid en daarmee ook in de maatschappij sterk te verbeteren.

\section{Referenties}

College voor de Rechten van de Mens, De positie van mensen met een arbeidsbeperking van jongs af aan in het licht van het VN-verdrag Handicap, breed advies 27 februari 2020a, p. 23-25.

College voor de Rechten van de Mens, Participatie van mensen met een beperking bij de totstandkoming van wetgeving en beleid, jaarlijkse rapportage 2020b, p. 21-23. E.A. Alkema, AB 2015/21, m.nt. S. Philipsen en J.C. de Wit, AA20150305, m.nt. R.J.B. Schutgens. 
Committee on the Rights of Persons with Disabilities, General comment No. 7 (2018) on the participation of persons with disabilities, including children with disabilities, through their representative organizations, in the implementation and monitoring of the Convention, p. 1.

Dijkstra, E. 'Wanneer je leven bepaald wordt door de wet - over handicap, regelgeving en identiteit', Handicap \& Recht 2020-2, p. 42.

Dijkstra, E., 'Het standstillbeginsel en de uitvoering van het VN-verdrag Handicap', Handicap \& Recht 2021-1, p. 21-27.

Disability studies in Nederland, Verbinding in de context, 2011, p. 19-20.

Hosselaar, J.H., 'En nu mét mensen met een beperking', Handicap \& Recht 2021-1, p. 17-20.

Nibud, Inkomenseffecten van het afschaffen van de Wtcg, CER en de Regeling specifieke zorgkosten, 2013.

Ogier, J.S., 'Ervaringsdeskundigen tegen loondispensatie', Handicap \& Recht 2018-2, p. 3742.

Pulles, G.J.W., 'Een verdrag met potentieel vérstrekkende gevolgen, de toepassing van het VN-verdrag Handicap door de Nederlandse rechter', Handicap \& Recht 2017-1, p. 5-6.

Sociaal en Cultureel Planbureau, Lang niet toegankelijk, juni 2021, p. 45-54. 